\title{
İlaç Kullanımı ile Oluşan Cilt Reaksiyonları
}

Skin Reactions Related To Drug Use

Didem OĞAN ${ }^{1}$, Miriş DİKMEN ${ }^{2}$

\section{öz}

İlaç kullanımına bağlı ortaya çıkan advers etkiler arasında cilt reaksiyonları sik görülen bir sağlık sorunudur. Özellikle ilaçların sistemik veya lokal olarak kullanımından sonra, ciddi advers etkiler görülmekte ve bunlardan cilt reaksiyonları da klinikte en sik rastlanılanlar arasındadır. Bu advers etkilerin büyük bir bölümü şiddetli olmamakla birlikte, nadir görülen bazı cilt reaksiyonları ise ölümle sonuçlanabilmektedir. İlaç kullanımına bağlı olarak meydana gelen cilt reaksiyonları, immünolojik ve immünolojik olmayan mekanizmalarla ortaya çıkmaktadır.

$\mathrm{Bu}$ derlemede özellikle akut ve kronik ilaç kullanımına bağlı olarak ortaya çıkan cilt reaksiyonları ve bu reaksiyonlara neden olan ilaçlar hakkında bilgiler derlenmiştir.

Anahtar Kelimeler: Advers Etkiler, Cilt, İlaç, İmmünoloji

\begin{abstract}
Skin reactions are a common health problem among drug-related adverse effects. Especially after the use of drugs systemically or locally, serious adverse reactions are seen and also skin reactions are among the most common ones in the clinic. Although most of these adverse effects are not severe, some rare skin diseases can result in death.

Skin reactions due to drug use occur with immunological and non-immunological mechanisms. In this review, skin reactions due to acute and chronic drug use and information about the drugs that cause these reactions have been rewieved.
\end{abstract}

Keywords: Adverse Effects, Drug, Immunology, Skin

* Bu derleme Anadolu Üniversitesi Eczacılık Fakültesi, 5. Sinıf öğrencisi Ecz. Didem Oğlan'ın 2018 yılı Mezunivet Projesinden hazırlanmıștır (Danışman: Prof..Dr. Miriş Dikmen).

${ }^{1}$ Eczac1, Maltepe Eczanesi, Adapazar1-Sakarya, didemogan@gmail.com, ORCID: 0000-0001-9766-0299

${ }^{2}$ Prof. Dr., Anadolu Üniversitesi, Eczacılık Fakültesi, Farmakoloji ABD, Eskişehir, mirisd@anadolu.edu.tr, ORCID: 0000-0002-9856-3148 


\section{GIRISS}

İstenmeyen ilaç reaksiyonları (ADR, Advers ilaç reaksiyonu), hastalığı önleme, tanı veya tedavi için kullanılan dozlarda meydana gelen, ilaca karşı zararlı veya istenmeyen bir reaksiyon olarak tanımlanmaktadır. ADR'ler günlük klinik uygulamalarda yaygındır ve hastaların \%15 ila \%25'ini etkilemektedir. Hastaların \%7-13' ünde ciddi reaksiyonların görüldüğü bildirilmiştir. $^{1}$ Tedavide ilaçların sistemik veya lokal olarak kullanımından sonra, advers etkilerle karşılaşılabildiği bilinmekte ve bunlardan cilt reaksiyonları da klinikte en sik rastlanılanlar arasındadır. İlacın neden olduğu deri döküntülerinin yaklaşık \% 2'si, Dünya Sağlık Örgütü'nün ciddi bir reaksiyon tanımını karşılamaktadır. İlaca bağlı cilt reaksiyonlarının çoğunun kesin mekanizması tam olarak anlaşılmamıştır ve hem immünolojik hem de immünolojik olmayan mekanizmalarından kaynaklanabileceği açıklanmıştır. $^{2}$

Cilt ilaç reaksiyonlarının büyük çoğunluğu, immünolojik olmayan mekanizmalarla ortaya çıkar. İmmünolojik reaksiyonlar konakç1-immünolojik yolların aktivasyonunu gerektirir ve ilaç alerjileri olarak tanımlanır. İmmünolojik olmayan mekanizmalarla meydana gelen ilaç reaksiyonları, efektör yolaklarının, aşırı dozun, kümülatif toksisitenin, advers etkilerin, ekolojik bozukluğun, ilaçlar arasındaki etkileşimlerin, metabolik değişikliklerin, önceden dermatolojik koşulların alevlenmesinin veya kalıtsal protein veya enzim eksikliklerinin aktivasyonuna bağlı olabilir. Bazı ilaçların neden olduğu cilt reaksiyonlarının mekanizmasi ise tam olarak bilinmemektedir. $^{3}$

Bağışıklıkla ilgili reaksiyonlar arasında, ekzantematöz ilaç reaksiyonları (tip IVb, T lenfosit-eozinofil-arac1li; tip IVc, T lenfositsitotoksik-aracil1); anafilaksi (tip I, IgE [immünoglobulin E]); anjiyoödem (tip 1, $\mathrm{IgE}$ ); ürtiker (tip 1, IgE); alerjik kontakt dermatit (tip IVa, T lenfosit-makrofaj aracıli); ilaç hipersensitivite sendromu (DHS; tip IVb, $\mathrm{T}$ lenfosit-eozinofil-aracıl1); sabit ilaç döküntüleri; eritema multiforme; ve serum hastalığı benzeri reaksiyonlar yer almaktadır. ${ }^{1,4}$ İmmün olmayan cilt reaksiyonlarına, ilaca bağlı tırnak değişiklikleri, hiperpigmentasyon ve cilt rengi değişiklikler, psödoallerji ve selektif kutanöz reaksiyonları sayılabilir. ${ }^{4}$

Dermatolojik ilaç reaksiyonların çoğu makulopapüler ekzantem veya ürtiker olarak görülmekle birlikte, ciddi kutanöz advers reaksiyonlar 1000 hastanın 1'inde görüldüğü rapor edilmiştir. ${ }^{5}$ Bir ilaca bağlı cilt reaksiyonu, ilk dozdan hemen sonra veya bir süre sonra meydana gelebilmekte fakat pigmentasyon, tırnak değişiklikleri veya saç üzerindeki etkiler birkaç ay sonra ortaya çıkmaktadır. ${ }^{3}$ İlaca bağlı cilt reaksiyonları akut ilaç kullanımına bağlı ortaya çıkan (eritematöz döküntüler, ürtiker, anjiyoödem ve anafilaksi, sabit ilaç erüpsiyonu, fotosensitivite, DRESS sendromu (ilaç aşırı duyarlıl1k sendromu), SJS (Stevens-Johnson Syndrome), TEN (toxic epidermal necrolysis ), varfarine bağlı deri nekrozu, DIV (drug induced vasculitis), AGEP (Acute Generalised Exanthematous Pustulosis), serum hastalığ ilaç kullanımına bağlı oluşan reaksiyonlar (akneiform döküntüler, pigmentasyon değişiklikleri, ilaca bağlı lupus) ve diğer cilt reaksiyonları (psöriaziform kabarmalar, likenoid ilaç erüpsiyonları, tırnak değişiklikleri, cilt kanseri) olarak sinıflandırılır. Özellikle bu cilt reaksiyonlarının belirtileri, ilaç kullanımına başlanmasından ne kadar süre sonra ortaya çıktığı ve tedavi yöntemleri akut ve kronik ilaç kullanımında oldukça önem taşımaktadır. Bu nedenle ciltte oluşan advers etkileri tanıyıp zamanında müdahale edilebilmesi hastalığın önlenmesi açısından önemlidir. ${ }^{2,6}$ 
Bağlı Meydana

Akut İlaç Kullanımına

Gelen Cilt Reaksiyonları

\section{Eritematöz Döküntüler}

İlaç döküntüleri olarak adlandırılan bu reaksiyonlar en sık karşılaşılan ADR'ler olarak bildirilmiştir. Benign ilaç döküntülerinin tüm kutanöz ADR'lerin \%90'ını oluşturduğu gösterilmiștir. ${ }^{6} \mathrm{Bu}$ döküntülerin tip IV gecikmiş hücre aracilı aşırı duyarlılık reaksiyonu olduğu düşünülmektedir. ${ }^{2}$ Neden olan ilaç kullanımı başladiktan sonra, 1 hafta içinde ortaya çıkmakta ve 7-14 günde gerilemektedir ${ }^{7}$ (Tablo 1).

Tablo 1. Akut İlaç Kullanımına Bağlı Oluşabilecek Cilt Reaksiyonları

\begin{tabular}{|c|c|c|}
\hline $\begin{array}{l}\text { Cilt } \\
\text { Reaksiyonları }\end{array}$ & Neden Olabilecek İlaçlar & Kaynaklar \\
\hline $\begin{array}{l}\text { Eritematöz } \\
\text { Döküntüler }\end{array}$ & $\begin{array}{l}\text { Penisilinler, Sefalosporinler, Sülfonamitler, Antikonvülzanlar, } \\
\text { Allopurinol }\end{array}$ & $(2,4)$ \\
\hline $\begin{array}{l}\text { Ürtiker } \\
\text { Anjiyoödem } \\
\text { Anaflaksi }\end{array}$ & $\begin{array}{l}\text { NSAİ, Antibiyotikler, ACE inhibitörleri, Lidokain, Prokainamid, } \\
\text { Kinidin, Kortikosteroidler, Antikanser ilaçlar, Monoklonal antikorlar }\end{array}$ & $(1,4,6,9)$ \\
\hline $\begin{array}{l}\text { Sabit İlaç } \\
\text { Erüpsiyonu }\end{array}$ & $\begin{array}{l}\text { İmmünsüpresif maddeler, Fenitoin, Hidroksiüre, Karbamazepin, } \\
\text { Amilorid, Allopurinol, Diltiazem, Klomipramin, Siklosporin }\end{array}$ & $(1,7,20)$ \\
\hline Fotosensitivite & $\begin{array}{l}\text { Amiodaron, Tetrasiklinler, NSAİI, Sülfonamidler, Sülfonilüreler, } \\
\text { Tiyazidler, Klorokin, Karbamazepin Amiodaron, Tetrasiklinler, } \\
\text { Psoralenler, Kömür katranı }\end{array}$ & (8) \\
\hline DRESS Sendromu & $\begin{array}{l}\text { Allopurinoller, Altın tuzları, Sülfonamidler, Antikonvülzanlar, } \\
\text { Dapson, Minoksilin, }\end{array}$ & (10) \\
\hline $\begin{array}{l}\text { SJS/ } \\
\text { TEN }\end{array}$ & $\begin{array}{l}\text { Sülfonamidler, Penisilinler, Lamotrijin, NSAIII, Karbamazepin, } \\
\text { Fenitoin, Sefalosporinler, Rifampisin, Allopurinol, Siklofosfamid, }\end{array}$ & $(1,3)$ \\
\hline İlaca Bağlı Vaskülit & $\begin{array}{l}\text { Allopurinol, NSAİI, Simetidin, Penisilin, Sefalosporinler, Hidantoin, } \\
\text { Minoksilin, Florokinolonlar, Sülfonamidler, İzotretinoin, Metotreksat }\end{array}$ & $(1,2,6)$ \\
\hline $\begin{array}{l}\text { Serum Hastalığı Benzeri } \\
\text { Reaksiyonlar }\end{array}$ & Minosiklin, Propronolol, Penisilinler & (2) \\
\hline AGEP & $\begin{array}{l}\text { Aminopenisilinler, Makrolidler, Kinolonlar, Diltiazem, Antimalaryal } \\
\text { ilaçlar }\end{array}$ & $(1,2)$ \\
\hline
\end{tabular}

Lezyonlar simetrik eritemli maküller veya papüller olup pruritik olabilmektedir. İlerlemeden önce genellikle gövde veya üst ekstremitelerde gelişmektedir. ${ }^{2}$ Cilt lezyonları vücudun geniş alanlarını kaplayacak şekilde simetrik olarak ilerleyebilmektedir. Düşük dereceli ateş çoğunlukla oluşan döküntülerle ilişkilendirilmektedir. Bazı durumlarda bu döküntüler daha şiddetli reaksiyonlara kadar ilerleyebilmektedir. $^{6}$

Birincil tedavi, neden olan ilacı bırakmaktır. İlaç temel tedavide gerekliyse oluşan eritematöz döküntü ile ilgili semptomlar daha ciddi bir reaksiyona sebep olmadığı sürece topikal/sistemik kortikosteroidler veya antipruritik ajanlar kullanılarak ilaç kullanımı devam ettirilmektedir. Daha şiddetli reaksiyonların ortaya çıkmadığından emin olabilmek için döküntüler ilk 48 saat boyunca izlenmektedir. $^{2}$

\section{Ürtiker, Anjiyoödem ve Anafilaksi}

Ürtiker (kovanlar) anafilaksinin kutanöz belirtileri olarak tanımlanmaktadır. Gelişmekte olan bir anafilaktik reaksiyonun ilk semptomu olabilen, IgE ile ilişkili (tip 1) bir alerjik reaksiyondur. Kovanlar oldukça kaşıntılı, eritemli, ödemli papül ve plaklarla karakterize oluşum göstermektedir. 


\section{Fotosensitivite}

küçük papüller olabileceği gibi alerjik reaksiyonlarda görülen büyük birleșebilen plakların görülebileceği de açıklanmıștır. ${ }^{8}$ Belirtilerin başlangıcı hızlı olmakla birlikte lezyonlar 24 saatten uzun sürmemektedir ancak yeni lezyon çıkışı bir süre devam edebilmektedir. $^{7}$

Anjioödem, deri ve deri altı dokuları kapsayan ve yüzü, bukkal mukozayı, dili, girtlak ve yutağı etkileyen soluk veya pembe şişlik olarak tanımlanmaktadır. Ürtiker ve anjiyoödem, solunum sıkışması, şok ve ölümle sonuçlanabilecek anafilaksi ile komplike olabilmektedir. ${ }^{2}$ Birçok ilaç anjioödem, ürtikere sebep olabilmektedir (Tablo 1).

İlk tedavi, neden olan ilacı kesmek olarak önerilmektedir. Gerekirse oral bir antihistamin kullanımı uygun olacaktır. Eğer şiddetli anjiyoödem ve anaflaksi varsa sistemik kortikosteroidler ve intramüsküler epinefrin enjeksiyonu ile tedavi önerilmektedir. 6,9

\section{Sabit (Fiks) İlaç Erüpsiyonu (Döküntü)}

$\mathrm{Bu}$ erüpsiyonların vücudun herhangi bir yerinde kırmızı, kaşıntılı, büyümüş lezyonlar olarak ortaya çıktığı, kabarcık veya plak haline gelebildiği bildirilmiștir. Lezyonlar birkaç dakika içerisinde ortaya çıkmakta olup bazı hastalarda yanma veya batma hissi olduğu rapor edilmiştir. Bu cilt reaksiyonunun mekanizması tam olarak bilinmemektedir. ${ }^{2}$

Tedavi, sebep olan ilacı bırakmak olarak uygulanmaktadır. Lezyonlar ilacin bırakılmasından sonra birkaç hafta içinde yerini pigmentasyona bırakarak iyileșir, ancak pigmentasyon aylarca kalabilmektedir. Tedavide aktif dönemde topikal steroidlerin yararlı olabileceği düşünülmektedir. Hasta soruna neden olan ilacı tekrar aldı ̆̆ında lezyonlar yeniden ortaya çıkabilmektedir ${ }^{7}$ (Tablo 1).
Fotosensitivite reaksiyonları, ilaçla güneș ışınlarının etkileşmesi sonucu meydana gelmektedir. Lezyonlar genellikle güneş gören yerlerde oluşmaktadır. Fotosensitivite reaksiyonu fotoalerjik veya fototoksik reaksiyon olarak ortaya çıkabilmektedir. ${ }^{7}$ Fototoksik reaksiyonların sik görülen ve öngörülebilen reaksiyonlar olduğu bildirilmiştir. $\mathrm{Bu}$ reaksiyonun sadece güneş gören bölgelerde meydana geldiği ve hızlı bir yanma hissi ile karakterize olduğu rapor edilmiștir. Fototoksik reaksiyona sebep olan ilaçlar mor ötesi A (UVA) 1şı ğını absorbe ederek hastalarda ciddi bir güneş yanığına ve sonrasinda hiperpigmentasyona sebep olabilmektedir. Fotoalerjik reaksiyonlar, immünolojik bir cevabın sonucu olarak ortaya çıkmaktadır. Fotoalerji ilacın UVA ile alerjenlere dönüşmesi sonucu oluşmaktadır. Güneşe maruz kalan ya da kalmayan cilt bölgelerinde görülebilmektedir. ${ }^{2}$ Fototoksik reaksiyonlara sebep olan ilaçlar amiodaron, tetrasiklinler, sülfonamitler, psoralenler ve kömür katranı; fotoalerjik reaksiyonlara sebep olan ilaçlar ise sülfonamidler, sülfonilüreler, tiyazidler, NSAIII (non-streoid antiinflamatuarilaç)'lar, klorokin ve karbamazepin olarak siralanabilir. ${ }^{8,9}$

\section{İlaç Aşırı Duyarlılık Sendromu}

DRESS sendromu olarak da adlandırılan ilaç aşırı duyarlılık sendromu nadir görülen, ateş, deri döküntüsü, lenfadenopati, hematolojik anormallikler (eozinofili, atipik lenfositler), iç organ (karaciğer veya diğer) tutulumu ile karakterize olarak yaşamı tehdit edebilen, gecikmiş tip ilaç hipersensitivite reaksiyonu olarak tanımlanmaktadır. ${ }^{10}$ İlaç maruziyetinden 2-6 hafta sonra başlamaktadır. Teşhis edilmesi zor olan bir sendrom olmasinın nedenleri, hastalık semptomlarının karmaşık seyretmesi olarak bildirilmiştir. Ateş, lenfadenopati, yanan ağrı gibi belirtiler cilt reaksiyonlarının ortaya çıkmasından 2 hafta önce görülebilmektedir. Klinik dermatolojik belirtiler arasında bulunan döküntünün eritrodermiye kadar ilerleyebilen spesifik olmayan bir morbiliform döküntü olarak başladığı bildirilmiștir. Yüz 
ödemi, eritroderma, distal ödem, püstüller, purpura ve bazen görülen fokal mukozal tutulum diğer klinik dermatolojik belirtiler arasında rapor edilmiştir. ${ }^{11}$

DRESS sendromunda en fazla görülen iç organ tutulumu karaciğer tutulumu olarak bildirilmektedir. Bu durumda hastada hepatik sitoliz, kolestaz ve nadiren hepatik yetmezlik görüldüğü rapor edilmiş̧tir. Diğer etkilenen organlar böbrek, kalp ve akciğer olarak bildirilmiştir. Böbrek tutulumu, interstisyel nefrit ile karakterize edilmiștir. Akciğer tutulumunun akut interstisyel pnömoni, plevrit veya erişkin solunum sıkıntısı sendromu ile komplike olabilen verimsiz öksürük veya nefes darlığı olarak görüldüğ̈̈ rapor edilmiştir. Kalp tutulumunda ise perikardit, miyokardit ve enzim anormallikleri gibi ölümcül olabilecek semptomlarla karşılaşılabilinmektedir. Bunlardan başka DRESS sendromunun tek veya çoklu insan herpes virüs aile üyelerinden olan Epstein-Barr virüsü [EBV], sitomegalovirüs ve parvovirüs B19 gibi virüslerin yeniden aktivasyonuna yol açabildiği bildirilmiştir. Bu viral aktivasyon, sendromun başlangicından 2-3 hafta sonrasına kadar tespit edilebilmektedir. ${ }^{5,12}$

DRESS sendromunun patogenezi tam olarak anlaşılamamıştır. Deri veya karaciğer hücrelerine karşı otoimmün yanıtları tetikleyen zararlı metabolitlerin birikmesine yol açan ilaç detoksifikasyon yollarının başarısızlığının, DRESS gelişiminde önemli bir rol oynadığı ileri sürülmüştür. Başka bir hipotezde immünolojik bir mekanizmanın DRESS sendromuna neden olduğu düşünülmekte ve gecikmiş bir hücre aracılı immün model olduğu önerilmektedir. Başka bir patofizyolojik mekanizma ise yukarıda bahsedilen yeniden viral aktifleştirmeyi içermektedir. ${ }^{6}$ Tedavi, neden olan ilacı bırakmak olarak uygulanmaktadır (Tablo 1). Döküntü ve visseral tutulum, ilacı bıraktıktan sonra birkaç hafta süreyle kalabilmektedir. ${ }^{2,13}$

\section{Stevens-Johnson Sendromu (SJS) ve Toksik Epidermal Nekroliz (TEN)}

Stevens-Johnson sendromu (SJS) ve toksik epidermal nekroliz (TEN) en ciddi ve hayatı tehdit eden kutanöz ADR'ler olarak bildirilmiştir. $\mathrm{Bu}$ hastalıkların yaygın olarak keratinosit ölümü, muköz membran erozyonlarıyla geniş epidermal kayba neden olduğu rapor edilmiştir. ${ }^{6}$ SJS epidermal hücrelerde nekroz oluşumuna sebep olan ilaç alerji hastalığı olarak tanımlanmıştır ve ilk kez 1922 y1lında Stevens ve Johnson isimli iki hekim tarafından akut pürülan konjonktivit, ciddi stomatit ve eritema multiforme benzeri deri lezyonları ile saptanmıștır. ${ }^{14,15}$ SJS daha çok ilaçlara ve enfeksiyonlara karşı oluşan, ateş, stomatit ve konjonktivit ile karakterize ağır bir cilt reaksiyonudur. Her yaş ve cinsiyette ortaya çıkabilmektedir. Geriatrik yaş grubunda da amoksisiline bağlı SJS vakaları nadir de olsa gelişebildiği rapor edilmiştir. ${ }^{16}$ TEN ise daha sonra 1956 yılında Alan Lyell tarafindan cildin haşlanmasına benzer bir erüpsiyon olarak rapor edilmiştir. ${ }^{14}$, ${ }^{15}$ Klinikte bu iki hastalık birbirinden vücut yüzey alanına bakılarak ayırt edilmektedir. \% 10 'dan az cilt hasarı varsa SJS, \% 30'dan fazla epidermal ayrılma var ise TEN, \% 10-\% 30 arasında kalan cilt sorunları ise SJS-TEN olarak tanımlanmaktadır. ${ }^{15}$

SJS ve TEN'in mor maküllerden oluşan kabarcıklara ve erozyonlara yol açtığı, cilt ve muköz zarlarda ağrılı lezyonlara neden olduğu ve hızlı ilerlediği bildirilmiştir. Hastaların yüksek ateş ve şiddetli halsizliğe sahip olduğu ve sistemik bulguların hepatik enzimlerin hafif yükselmesi, bağırsak ve akciğer bulguları ile epitelin parçalanması olduğu rapor edilmiştir. Hastaların solunum sistemi bulgularının hızla bozulduğu bildirilmiştir. Lezyonların hızlı birleşme ve yayılma göstererek geniş epidermal ayrılma ve kanamalara neden olduğu bu durumun da sıv1 kaybına ve ikincil enfeksiyonlara yol açabileceği düşünülmektedir. ${ }^{6,8}$ StevensJohnson sendromu ve toksik epidermal nekroliz tanısı için spesifik bir skor veya tanı testi yoktur. Teşhis çoğunlukla geniş bir klinik bulgu ve semptomların ve histolojik testlerin tanımlanmasına dayanmaktadır. ${ }^{12}$ 
SJS'nin tanımlanmasında Nikolsky
klinikte ayırıcı tanı olarak kullanılmaktadır. Bu bulgunun (+) olarak değerlendirilebilmesi için hastada bazal tabakadaki hücre ölümleri sonucu dermoepidermal bileşkede ayrışma ve bunu takiben bül oluşumunun görülmesi ve bu bülün lateral kısmına uygulanan hafif bir basınçla nekrotik epidermiste soyulma meydana gelmesi gerektiği bildirilmiştir. ${ }^{14} \mathrm{Bu}$ reaksiyonlara ilişkili olan ilaçlar Tablo 1'de gösterilmiştir.

\section{Varfarine Bağlı Deri Nekrozu}

Warfarine bağlı cilt reaksiyonları fotosensitivite, makulopapular vesiküler ürtikeryal döküntüler, cilt doku nekrozu ve vaskülit olarak ortaya çıkmaktadır. ${ }^{17}$ Özellikle varfarine bağlı deri nekrozu, hastanın varfarini kullanmaya başlamasından 3-5 gün sonra ortaya çıkabilen nadir fakat ciddi bir bozukluk olarak tanımlanmıştır. Nekrozun varfarin kullanan 10.000 hastada bir görüldüğü rapor edilmiştir. Kırmızı, ağrılı plak oluşumuyla başladığı sonrasında nekroza, ülserlere ve hemorajik kabarcıklara dönüştüğü bildirilmiştir. ${ }^{2}$

Protein C'de kalitsal bir eksiklik olan hastaların daha fazla risk altında olduğu açıklanmıştır. Geç başlangıçlı varfarin kaynaklı cilt nekrozunun olası nedenleri arasında, karaciğerin sentez fonksiyonunda ani bir düşüş ve sodyum salisilat ve ibuprofen gibi ilaç etkileşimleri belirtilmiştir. ${ }^{2,18}$

\section{İlaca Bağlı Vaskülit (DIV)}

Vaskülit inflamasyon ve kan damarı duvarının hasarı ile karakterize edilen patolojik bir süreç olarak tanımlanmaktadır. $\mathrm{Bu}$ reaksiyonlarda cilt tek etkilenen organ olabileceği gibi iç organların tutulumu da vaskülitin bir parçası olabilmektedir. Deride bulunan post-kapiller damarları etkileyen cilt küçük damar vaskülitinin, ciltte görülen en yaygın vaskülit formu olduğu rapor edilmiştir. Ciltte en belirgin bulgusu ürtikeryal lezyonlar, ülserler ve hemorajik kabarcıklar ile birlikte yaygınlaşabilen veya sınırlı olabilen palpatif lezyonlardır. Lezyonlar özellikle alt bacaklara yakın bölgelerde görülmektedir. Yanma, ağrı ve nadiren pruritis yaşanabilmektedir.
Vaskülitin aynı zamanda nadir de olsa böbrek, karaciğer ve gastrointestinal sistemdeki damarları da etkileyebildiği ve bu durumda hayati tehlike oluşturabileceği bildirilmiştir. İlaç kullanılmasından (Tablo 1) sonra bulguların ortaya çıkması birkaç gün ile haftalar arasında değişmektedir. Mekanizma tam olarak bilinmemektedir., ${ }^{3,6}$ Tedavide, neden olan ilaç hemen bırakılarak topikal kortikosteroidler ve oral antihistaminikler kullanılmaktadır. ${ }^{2,6,19}$

\section{Serum Hastalığı Benzeri Reaksiyonlar}

Serum hastalığı benzeri reaksiyonlar, ateş, kızarıklık ve artraljiler ile meydana gelen komplike ürtikeryal döküntüler olarak tanımlanmaktadır. $\mathrm{Bu}$ reaksiyonların genellikle ilaca başladıktan (Tablo 1) 1-3 hafta sonra ortaya çıktığı bildirilmiştir. Reaksiyon fark edildiğinde kullanılan etken maddenin bırakılması gerektiği, eğer şiddetli belirtiler varsa tedavide sistemik kortikosteroid kullanımına gerek duyulabileceği bildirilmiştir. Dolaşımda immün komplekslerin olmaması ve düşük kompleman seviyeleri ile serum hastalığında ayrilır. Hastada immün komplekslerin olmaması, vaskülit veya böbrek lezyonlarının bulunmaması nedeniyle, bu reaksiyonun gerçek bir serum hastalığı olmadığı rapor edilmiştir. ${ }^{2,8}$

\section{Akut Generalize Ekzantematöz Püstülozis (AGEP)}

S1klıkla lökositozla seyreden akut febril bir durum olarak tanımlanmaktadır. İlaç alımını takiben 1-3 haftada genellikle yüzde ve kıvrım yerlerinde ortaya çıkan ateş, kaşınma yanma ile yaygın, eritemli zeminde püstüller ile karakterize edilmiştir. Bunu takiben gövde ve ekstremitelerde çok küçük folikül diş1 püstüllerin oluştuğu gözlemlenmiştir. İç organ tutulumunun nadir olarak görüldügü ve genellikle kreatinin klirensinde hafif bir azalma, hafif aminotransferaz yükselmesi ve hipokalsemi ile sınırlı olduğu bildirilmiştir. ${ }^{6,7}$, 12 Tedavide ilk yapılacak şey reaksiyon fark edildiğinde, neden olan ilacin (Tablo 1) hemen bırakılması olarak bildirilmiştir. İlaç bırakıldıktan sonra hızlı bir șekilde düzelme olması gerektiği, bazen antiprüritik bir ajan 
veya sistemik kortikosteroidlerin kısa süreli kullanımının gerekebileceği bildirilmiştir., ${ }^{2,6}$

\section{Kronik İlaç Kullanımına Bağlı Meydana Gelen Cilt Reaksiyonları}

\section{Akneiform Döküntüler}

İlaca bağlı akne bulguları gerçek akneye benzeyen yaygın olarak görülen basit püstüler patlamalar olarak tanımlanmaktadır. Yaygın olarak görülen sivilceden belirli farklarının olduğu ve klinikte tanı koyabilmek için bu kriterlere bakıldığ 1 bildirilmiştir. $\mathrm{Bu}$ farklılıklar hastanın ilaç kullanma öyküsünün bulunmas1, döküntülerin ani başlaması, akne bașlangıcının beklenmediği bir yaș aralığında oluşması, yüzde ve boyunda görülmesi ve seboreik alanların ötesinde lezyonların alışılmadık yerlerde ortaya çıkması olarak rapor edilmiştir. Döküntüler iltihaplı papül veya papülopüstüllerden oluşmaktadır eğer komedonlar varsa bunlar sekonder lezyonlar olarak bildirilmiştir. Reaksiyon genellikle 1-3 hafta arasında ortaya çıkmaktadır., ${ }^{8,21}$ Akne oluşumunda sebum atılımının derecesi, folliküler hiperkeratozis, hormonal etki ve bezin bakteriyolojisi olmak üzere dört ana faktörün rol oynadığı ve bu faktörleri etkileyen ilaçların akneye sebep olabileceği bildirilmiștir (Tablo 2). Mevcut lezyonların tedavisi için neden olan ilacı bıraktıktan sonra topikal antibiyotikler ve benzoil peroksit kullanılması önerilmektedir. ${ }^{7}$

\section{Pigmentasyon Değișiklikleri}

İlaca bağl1 pigmentatif değișikliklerin melanin üretiminin artması, ilaçların veya metabolitlerinin çökmesi, fototoksisite, sekonder olarak ortaya çıkan iltihap sonrası değişiklikler de dahil olmak üzere farklı mekanizmalarla ortaya çıkabildiği bildirilmiştir. Etkiler çoğunlukla güneş gören yerlerde gri, morumsu, kahverengi renk değişiklikleri ile ortaya çıkmaktadır. ${ }^{2,7}$ Pigmentasyonun tedavisinde ilacin (Tablo 2) kesilmesi önerilmektedir, buna ek olarak kozmetik renk açıcıların kullanılabileceği rapor edilmiştir. Pigmenter değişiklikler zamanla kaybolabilmekte, çok az sayıda hastada kalıc1 olabilmektedir. ${ }^{2,3,7}$

\section{İlaca Bağlı Lupus}

Nadir görülen bir advers etki olarak ortaya çıkan, ilaca bağlı lupus eritematozus (İLE) lupus benzeri bir tablo olup, ilacin kesilmesi ile birlikte düzelir. Lupus lokalize kutanöz bir formdan yaşamı tehdit edebilen sistemik bir forma kadar ilerleyebilen geniş klinik bulgular sergileyebilen otoimmün bir hastalık olarak tanımlanmaktadır. En yaygın klinik bulgular artralji, miyalji, artrit gibi kas-iskelet sitemi hastalıkları ve ateş, halsizlik, iştahsızlık, kilo verme gibi yapısal semptomlar olarak belgelenmiştir. ${ }^{2}$ Belirtilerin başlangıcının akut olabileceğini ancak sıklıkla ilaç kullanımının (Tablo 2) başlangıcından aylar sonra yavaş ve kademeli bir şekilde görüldüğünü bildirmiştir. ${ }^{2,22}$ Tedavi için ilacın bırakılması yeterli olmaktadır. Daha ağır vakalarda kortikosteroidler veya immünosupressif tedavi gerekli olabilmektedir. ${ }^{2}$

Tablo 2. Kronik İlaç Kullanımına Bağlı Olarak Oluşabilecek Cilt Reaksiyonları

\begin{tabular}{|c|c|c|}
\hline $\begin{array}{l}\text { Cilt } \\
\text { Reaksiyonları }\end{array}$ & Neden Olabilecek İlaçlar & Kaynaklar \\
\hline $\begin{array}{l}\text { Akneiform } \\
\text { Döküntüler }\end{array}$ & $\begin{array}{l}\text { Kortikosteroidler, Anabolik steroidler, Testesteron, İzoniazid, Halojenler, } \\
\text { Lityum Antikanser Ajanlar, Siklosporin, Takrolimus, Vitamin B12, } \\
\text { Vitamin D2, Fenobarbitüratlar, Tiyourasil Amoksapin, Azatiyopirin, } \\
\text { Disülfïram, TNF-A İnhibitörleri, Trisiklik Antidepresanlar }\end{array}$ & $(3,21)$ \\
\hline $\begin{array}{l}\text { Pigmentasyon } \\
\text { Değişiklikleri }\end{array}$ & $\begin{array}{l}\text { Fenotiazinler, Antimalaryal İlaçlar, Minosiklin, Gümüş, Altın, Bizmut, } \\
\text { Civa, Zidovüdin, Sitotoksik ilaçlar, Klofazimin, Metisergid, Oral } \\
\text { kontraseptifler, Nikotinik asit, Amiodaron, Adrenokortikropin }\end{array}$ & $(2,3)$ \\
\hline İlaca Bağlı Lupus & $\begin{array}{l}\text { Hidralazin, Prokainamid, Metildopa, Kaptopril, Asebutalol, Klorpromazin, } \\
\text { İzoniazid, Minoksilin, Karbamazepin, Sulfasalazin Propiltiourasil, } \\
\text { Penisilamin }\end{array}$ & (23) \\
\hline
\end{tabular}




\section{Tırnak Değișiklikleri}

\section{Psöriaziform Kabarmalar}

İlaçların psöriaziform kabarmalara sebep olabileceği veya var olan psöriazisi kötüleştirebileceği bildirilmiştir. İdiyopatik psöriazisten farklı olarak dizler ve dirseklerde yamalı eritem ve skala yapımı, avuç içi ve tabanda hiperkeratoz daha fazla görülmektedir. Reaksiyonun başlaması ilaç kullanımından (Tablo 3) hemen sonra olabileceği gibi bir yıl sonrasında da ortaya çıkabileceği ve reaksiyonun mekanizmasının tam olarak belirlenemediği bildirilmiştir., ${ }^{3,24}$

\section{Likenoid İlaç Erüpsiyonları}

Likenoid ilaç erüpsiyonları, idiyopatik liken planusa benzer şekilde ilerleyen patlamalar olarak tanımlanmaktadır. Meydana gelen lezyonlar küçük, parlak, çokgen papüller şeklinde bazen karakteristik beyaz çizgilerden oluşmaktadır. Genellikle kaşıntılı oldukları bazen de asemptomatik olabilecekleri bildirilmiştir. Likenoid ilaç erüpsiyonlarının geniş kapsamlı olma eğiliminde olduğu fakat bukkal mukozayı etkilemediği belgelenmiştir. $\mathrm{Bu}$ hastalığa neden olabilecek ilaçlar örnekleri Tablo 3'de ki verilmiştir. ${ }^{3}$
İlaca bağlı tırnak değişiklikleri tırnak kırılganlığı, parnezi, vasküler ve pigmentasyon değişikliklerini içermektedir. Etkilerin genellikle ilaçların (Tablo 3) bırakılması ile geçtiği bildirilmiştir. ${ }^{3}$

\section{Cilt Kanseri}

Deri kanserleri skuamöz hücre karsinomas1, habis melanoma ve bazal hücre karsinomas1 olarak siniflandirılmaktadır. Skuamöz hücreli karsinomun sert ten renginde veya eritemli papüller/plaklar olarak bulunabildiği ve daha çok yaşlılarda görüldügü bildirilmiştir. Risk faktörleri uzun süreli güneșe maruz kalma, uzun süreli uygulanan immünsupresif tedavi ve UV radyasyonu olarak rapor edilmiştir. ${ }^{8}$ Sedef hastalığında kullanılan PUVA (psoralen ve ultraviyole A) tedavisi almış olan hastaların deri kanseri riski, başlıca kümülatif UVA dozu ve tedavi seansı ile ilişkili bulunmuş ve zaman içinde artış gösterdiği saptanmıştır. ${ }^{25}$ Bazal hücre karsinoması (BHK) çoğunlukla baş ve boyunda renkli bir nodül olarak ortaya çıkan çok yaygın görülen bir deri hastalığıdır. BHK tedavisinde cerrahi eksizyon ve topikal ajanlar veya 5-fluorourasil gibi antineoplastik ajanlar kullanılmaktadır. ${ }^{8}$

Tablo 3. İlaç Kullanımına Bağlı Olarak Oluşabilecek Diğer Cilt Reaksiyonları

\begin{tabular}{llr}
\hline Cilt Reaksiyonları & Neden Olabilecek İlaçlar & Kaynaklar \\
\hline \multirow{2}{*}{ Psöriaziform Kabarmalar } & Lityum, Klorokin, NSAİ̇, $\beta$-blokörler, İnterferon alfa & $(3,24)$ \\
\hline \multirow{2}{*}{ Likenoid İlaç Erüpsiyonları } & Tiyazidler, Furosemid, Klorokin, Kinin, Fenitoin, & $(3)$ \\
& Streptomisin, Etambutol, Altın, Penisilamin, Enalapril, & \\
\hline \multirow{2}{*}{ Tirnak Değişiklikleri } & Tetrasiklinler, Tiyazidler, Kloramfenikol, Klorokin & $(3)$ \\
& Klorpromazin, Sitotoksik ilaçlar, & $(3,8)$ \\
\hline \multirow{2}{*}{ Cilt Kanseri } & İmmünsüpresif İlaçlar, Hidroksiüre, Fenitoin, PUVA & \\
\hline
\end{tabular}

Malign melanomlar, erken teşhis edilmezse sistemik metastazlar oluşturan bir hastalıktır. Hastalığın varlığında oluşan moller tam cilt muayeneleri ile tespit edilmektedir. $\mathrm{Bu}$ muayenelerde moller asimetri, düzensiz sınırlar, alacalı renkler ve ebat açısından incelenmektedir. Tedavide şüpheli lezyonların hemen alınması gerektiği ve metastatik melanomda temozolamid veya dakarbazin gibi sistemik antineoplastik ilaçların kullanıldığı belgelenmiştir. Risk faktörleri PUVA gibi ilaç tedavileri, sedef 
hastalığında kullanılan biyolojik yanıt modifiye ediciler, uzun süreli güneşe maruz kalma ve aile öyküsü olarak sıralanmaktadır.
Malign deri lezyonlarına neden olabilecek bazı ilaçlar Tablo 3 'te listelenmiștir. 3,8

\section{SONUÇ VE ÖNERILLER}

Akut ve kronik olarak ilaç kullanımına bağlı olarak meydana gelebilecek çok ciddi reaksiyonlarının iyi bilinmesi hastaların morbidite ve mortalitelerinin azaltılmasında önem taşımaktadır. Sağlık hizmetleri alanında, hastada oluşabilecek cilt reaksiyonları iyi değerlendirilmeli, hasta konu ile ilgili bilgilendirilmeli, gerekli görüldüğünde sorumlu ilacın kesilmesi ve ilaç reaksiyonun tipine göre uygun, tedaviler planlanmalidir

\section{KAYNAKLAR}

1. Warrington, R, Silviu Dan, F, Wong, T. (2018). "Drug allergy." Allergy Asthma Clin Immunol, 14 (2), 60

2. Clinard, V, Smith, J. (2012). "Drug-Induced Skin Disorders.' U.S. Pharm., 37, HS11-HS18.

3. Abdollahi, M, Karimpour, H, Khalai, S. (2003). "Review of drug-induced skin reactions." Journal of Pharmacy Practice and Research., 33, 12-15.

4. Gates, A, Cullen ,S, Nykamp, D. (2017). "Drug-Induced Hypersensitivity Reactions: Cutaneous Eruptions." US Pharm, 42(6), 32-36.

5. Chen, Y, Cho, Y, Chang, C, Chu, C. (2013). "Drug reaction with eosinophilia and systemic symptoms: A drug-induced hypersensitivity syndrome with variable clinical features." Dermatologica Sinica, 31, 196-204.

6. Marzano, A V, Borghi , A, Cugno, M. (2016). “Adverse drug reactions and organ damage: The skin." European Journal of Internal Medicine, 28, 17-24.

7. Yücel, A, Karakuş, G, Günaştı, S. (2008). "Psikotrop İlaçların Dermatolojik Yan Etkileri ve Tedavi Yaklaşımları.” Klinik Psikofarmakoloji Bülteni, 18, 235-244.

8. Law, R M, Law, D T S. (2014). "Dermatologic Drug Reactionsand Common Skin Conditions. Pharmacotherapy:A Pathophysiologic Approach", McGraw-Hill Education, United States of America, 347-358

9. Başar, I, Aydemir, E H.(2014) “ Kardiyovasküler İlaçlar ve Dermatolojik Yan Etkileri.” Cerrahpaşa Tıp Dergisi, 30, 286297.

10. Canitez, Y, Poyraz, E H, Sapan,, N. (2015). "Karbamazepine Bağlı Dress Sendromu; Nadir Görülen Bir İlaç Hipersensitivite Reaksiyonu." Türkiye Çocuk Hastalıkları Dergisi, 1, 147-151.

11. Iskandarli, M, Türk, B, Sentürk, B, Yaman, B, Kandiloğlu, G, Öztürk, G.(2015). “ Sülfasalazin İlişkili DRESS Sendromu.”.http://www.dermatoz.org/2015/3/dermatoz15063 o3.pdf

12. Duong, T, Allanore, L, Wolkenstein, P, Chosidow, O. (2017) "Severe Cutaneous Adverse Reactions to Drug." Lancet, 390, 1996-2011

13. Hiransuthikul, A, Rattananupong, T, Klaewsongkram, J, Rerknimitr, P, Pongprutthipan, M, Ruxrungtham, K. (2016). "Drug-induced hypersensitivity syndrome/drug reaction with eosinophilia and systemic symptoms (DIHS/DRESS): 11 years retrospective study in Thailand." Allergology International, 65, 432-438.
14. Cura, S, Acaroğlu ,R.( 2017). “ Nadir Bir Hastalık: Stevens Johnson Sendromlu Bireyin Yaşam Modeli Doğrultusunda Bakımı.” Florence Nightingale Hemşirelik Dergisi, 25, 219. 226

15. Akan, A, Erkoçoğlu, M, Kaya, A, Toyran, M, Civelek, E, Savaş, Z, Azkur, D, Dibek Misırlığlu, E, Kocabaș, C N.(2013). "Stevens-Johnson sendromu ve toksik epidermal nekrolizisli çocuk hastalarda intravenöz immünglobulin tedavisi ve literatürün gözden geçirilmesi." Asthma Allergy Immunol,11, 197-203.

16. Önder, E, Güngör, A, Celbek, G, Çeçen, F, Yıldırım, Ü Gürlevik, Z, Aydın, Y, Cinemre, H. (2010).” Geriatrik Yașta Amoksisilin Kullanımı Sonucu Gelişen ve Hayatı Tehdit Eden Ağır Stevens Johnson Sendromu." Turkish Journal of Geriatrics, 13, 36-40.

17. Bulcun, E, Ekici, A, Ekici, M, Anıl, Karabulut, A, Cerit, A.( 2016). "Warfarinle ilişsili lökositoklastik vaskülit ve cilt nekrozlu olgu.” İzmir Göğüs Hastanesi Dergisi. 30, 133-136.

18. Pero, M, Verma, S, Espeso, A, Griffiths, M, Jani, P. (2009). "An unusual case of warfarin-induced pinna skin necrosis." The Journal of Laryngology \& Otology. 123, 685-688.

19. Raiker, N, Aouthmany, M, Ezra, N.(2016). " Dermatologic Signs and Symptoms of Substance Abuse." J. Clin. Exp. Dermatol. Res, 7, 1-7.

20. Hyson, C, Sadler, M. (1997). "Cross Sensitivity of Skin Rashes with Antiepileptic Drugs.” Can. J. Neurol. Sci, 24, 245-249.

21. Kazandjieva, J, Tsankov, N. (2017). "Drug-induced acne." Clinics in Dermatology, 35, 156-162.

22. Ünlü, B, Türsen, Ü. (2018). "Autoimmune Skin Diseases and the Metabolic Syndrome." Clinics in Dermatology, 36, 67-71.

23. Rubin, R. (2005). "Drug-induced lupus.” Toxicology, 209, 135 147

24. Maroney, M E, Liu, M T, Smith, T, Thomas, K L.(2016). "Lithium." Side Effects of Drugs. Elseiver, New York, 21-28.

25. Aslan, M U, Ekinci , A P, Baykal, C. (2015). "PUVA tedavisi alan mikozis fungoides hastalarının deri kanseri riski: retrospektif bir çalışma.” Turk J Dermatol, 1, 12. 